\title{
MOLECULAR CLONING AND CHARACTERIZATION OF THE THREONINE DEAMINASE (ILVI) GENE OF SACCHAROMYCES CEREVISIAE
}

\author{
by \\ JENS G. LITSKE PETERSEN, STEEN HOLMBERG, \\ TORSTEN NILSSON-TILLGREN1) and MORTEN C. KIELLAND-BRANDT
}

\author{
Department of Physiology, Carlsberg Laboratory, \\ Gamle Carlsberg Vej 10, DK-2500 Copenhagen Valby \\ and \\ 1)Institute of Genetics, University of Copenhagen, \\ Øster Farimagsgade 2A, DK-1353 Copenhagen K.
}

\begin{abstract}
Keywords: Isoleucine biosynthesis, DNA and RNA hybridization, cosmids, gene disruption, pathway specific control, transcriptional regulation
\end{abstract}

The $I L V /$ gene from Saccharomyces cerevisiae coding for the anabolic threonine deaminase was isolated from a cosmid-yeast DNA gene pool on a $35 \mathrm{~kb}$ insert by transformation of a haploid $i l v /$ yeast mutant to isoleucine prototrophy. By subcloning, the functional gene was isolated on a $4.8 \mathrm{~kb}$ DNA fragment. Hybridization of radioactively labelled DNA fragments from the cloned region to electrophoretically separated yeast RNA showed that the ILVI mRNA is about 2,000 ribonucleotides long. This analysis revealed also the approximate position of the transcribed region. The location of the $I L V I$ gene in the cloned region was confirmed by gene splitting: The transformation of a wild type strain with a plasmid containing an internal fragment of the cloned gene caused inactivation of the chromosomal $l L V l$ gene. By RNA hybridization (Northern) analysis, a 5-10 fold decrease in the threonine deaminase mRNA level was observed in wild type cells when minimal medium with leucine was supplemented with isoleucine and valine. This indicates that $I L V I$ is under transcriptional control.

\section{INTRODUCTION}

The first enzyme in the isoleucine biosynthesis pathway is threonine deaminase or L-threonine hydro-lyase (deaminating) (EC 4.2.1.16). The enzyme converts threonine to $a$-ketobutyrate, which in turn is converted through four enzymatic steps to isoleucine. These four enzymes are shared by the biosynthetic pathway for valine starting from pyruvate. The immediate precursor for valine, $\alpha$-ketoisovaleric acid, serves as the starting point for the biosynthesis of leucine. The metabolic flow through the branched-chain amino acid pathways is controlled mainly by feed-back inhibition of the first enzyme of each path. In Saccharomyces cerevisiae threonine de-

Abbreviations: $\mathbf{k b}=$ kilo base (pairs); $\mathrm{NPD}=$ non-parental ditype; $\mathrm{PD}=$ parental ditype; $\mathrm{T}=$ tetratype 
aminase is inhibited by isoleucine $(1,19,36)$, acetohydroxyacid synthase by valine (36) and $\alpha$ isopropylmalate synthase by leucine $(38,45)$. The isoleucine-valine biosynthesis enzymes in yeast are regulated in a complex manner. They seem to be multivalently repressed by isoleucine, valine and leucine $(8,12)$. The last enzyme in the biosynthesis, transaminase $B$, has been shown to be under cross-pathway control (14), while the acetohydroxyacid synthase is not (47). The possible regulatory interactions have been discussed in detail in a recent review (18).

Threonine deaminase has been purified from a number of organisms, in several cases to homogeneity, c.f. review by UMBarger (46). The enzyme from the different sources shows several common features. It has a molecular weight of about 200,000 and is composed of two or four identical subunits. The enzyme from most organisms exhibits a simple hyperbolic substrate saturation curve, but in the presence of isoleucine, a sigmoid saturation curve is obtained. The inhibition and the cooperative binding is reversed by valine, which is a positive effector.

The yeast threonine deaminase $(1,4,19)$ is somewhat different, since the enzyme shows cooperative binding to threonine in the absence of isoleucine. Valine acts as a positive effector by transforming the sigmoidal response to substrate into a normal Michaelian relationship. The yeast threonine deaminase is also special by its ability to be activated by low isoleucine concentrations, otherwise only found in Pseudomonas multivarens (25). The yeast enzyme consists of four subunits with a molecular weight of approximately 50,000 (1). It has been shown to be located in the mitochondrion together with at least three of the other four isoleucine-valine enzymes $(23,37)$. The enzyme may have a coordinating role in the repression of the isoleucine-valine enzymes $(4,7,9,10)$.

So far, genes coding for threonine deaminase have been cloned from Escherichia coli $(13,29)$ and Salmonella typhimurium (6). We have recently analysed several isoleucine-valine mutants in yeast and mapped the chromosomal positions for two of the genes (34). As a further step in a study of the regulation of the isoleucinevaline pathway of yeast the present paper de- scribes cloning and analysis of the $I L V I$ gene, which codes for threonine deaminase.

\section{MATERIALS AND METHODS}

\subsection{Strains and media}

The following strains of Saccharomyces cerevisiae were employed: The wild-type strain S288C (MATa SUC2 CUPI gal2), C81-1431 (MATa ilvl-23 trpl ura4 arg4 ade2), C82-1748 (MATa ilv1-92 trpl hisl ura3 ade2 canl cyh2), C811615 (MATa ilv1-22 trpl ura3-52 arg4-16 ade2), K396-11A (MATa spoll ura3 adel hisl leu2 lys7 met3 trp5) (22), Ml-2B (MATa ura3-52 trpl) (42).

The Escherichia coli strains were $\mathrm{HB} 101$ ( $\mathrm{rec} A$ $h s d S$ ) and BJ5183 (recA recBC $s b c B$ endol hsd) (40).

LB medium was $10 \mathrm{~g}$ Difco Bacto Tryptone, 5 g Difco Bacto Yeast Extract, $10 \mathrm{~g}$ sodium chloride, $1 \mathrm{~g}$ glucose, $\mathrm{pH} 7.2$, per liter distilled water. Synthetic and rich media for yeast have been described (34).

\subsection{DNA purification}

Total yeast DNA was prepared by the guanidinium chloride method followed by cesium chloride equilibrium centrifugation (21). Small preparations of total yeast DNA were done essentially as described by STRUHL et al. (43). Plasmid DNA from yeast was prepared according to Livingston and KLEIN (26). Small scale plasmid DNA from yeast protoplasts and from E. coli were prepared by the alkaline extraction procedure of BirnBoIm and Doly (5). Plasmid DNA from $E$. coli was made by the cleared lysate procedure of KATZ et al. (20) or a scaled-up version of the alkaline extraction method followed by $\mathrm{CsCl}$ equilibrium centrifugation. Purification of DNA restriction fragments from agarose gels by electroelution onto a dialysis membrane was according to YANG et al. (48).

\subsection{RNA preparation}

The wild type strain $\mathrm{S} 288 \mathrm{C}$ was grown in minimal medium containing $5 \mathrm{~mm}$-isoleucine, 5 mm-valine and 5 mm-leucine (conditions repressing threonine deaminase activity) or $20 \mathrm{~mm}$-leucine (derepressing conditions) (8) at $30{ }^{\circ} \mathrm{C}$ to a density of $2 \cdot 10^{7} \mathrm{cells} \cdot \mathrm{ml}^{-1}$. For the preparation of total RNA the procedure described by BROACH et al. (11) was used. Enrich- 
ment for poly(A) RNA was performed by a single step of chromatography on poly(U) sepharose (Pharmacia).

\subsection{Enzymes and gel electrophoresis}

Restriction endonucleases, DNA polymerase I and T4 DNA ligase were obtained from Bethesda Research Laboratories, New England Biolabs or Boehringer Mannheim.

Electrophoresis of DNA was carried out in $0.7 \%$ agarose (Sigma) in TBE ( $85 \mathrm{~mm}$-Tris-OH, $89 \mathrm{~mm}$-boric acid, $2.5 \mathrm{~mm}-\mathrm{Na}_{2}$ EDTA) or in TAE (40 mM-Tris-OH, 20 mm-acetic acid, 2 mm$\mathrm{Na}_{2}$ EDTA).

Electrophoresis of RNA was in $1.5 \%$ agarose gels with formaldehyde (24).

\subsection{Preparation of a cosmid-yeast DNA gene pool}

Twenty $\mu \mathrm{g}$ of S288C DNA were cleaved partially with restriction enzyme Mbol. By electrophoresis it was assured that the majority of restriction fragments were $30-50 \mathrm{~kb}$ in size. The DNA fragments were ligated to $6 \mu \mathrm{g}$ of BamHI cleaved cosmid p2911 at a concentration of 960 $\mu \mathrm{g} \cdot \mathrm{ml}^{-1}$. The cosmid p2911 (kindly supplied by B. $\mathrm{HOHN}$ ) is a $7.8 \mathrm{~kb}$ plasmid with genes for ampicillin and tetracycline resistance, the $1.4 \mathrm{~kb}$ TRPI ARSI yeast DNA fragment and the cos site of bacteriophage $\lambda$. BamHI linearizes the plasmid and insertions in this site renders bacteria tetracycline sensitive.

The ligated DNA was packaged in vitro into phage $\lambda$ particles and transduced into $E$. coli strain HB101 (28). After transduction the cells were plated on $\mathrm{LB}$ agar with $25 \mu \mathrm{g} \cdot \mathrm{ml}^{-1}$ of ampicillin. A total of 12,000 colonies were obtained. Twelve randomly picked ampicillin resistant colonies were screened for plasmid content and were found to harbor recombinant plasmids with inserts ranging from 10 to $30 \mathrm{~kb}$. The 12,000 colonies were pooled and propagated for plasmid DNA preparation.

\subsection{Transformation}

Transformation of yeast followed the protoplast method of BEGGS (3) or the cation treatment method of ITo et al. (17) using lithium nitrate. Bacterial strains were transformed according to MANDEL and Higa (27).

\subsection{In vitro labelling, transfer of electrophoreti- cally separated DNA or RNA and hybridization}

Purified restriction fragments were labelled in vitro with 32P-dTTP (Radiochemical Centre Amersham or New England Nuclear) by nick translation according to RIGBY et al. (35). Specific radioactivities of $1-4 \cdot 10^{8} \mathrm{cpm} \cdot \mu \mathrm{g}^{-1}$ were obtained.

Electrophoretically separated DNA fragments in agarose gels were transferred to nitrocellulose filters (Millipore HAWP 000 10) by a modification of the procedure of SOUTHERn (41) as described previously (16). Hybridization of labelled DNA to DNA immobilized on nitrocellulose was performed as described (16).

RNA separated on $1.5 \%$ agarose formaldehyde gels was transferred to nitrocellulose filters (41). Hybridization of labelled DNA to the immobilized RNA was in $50 \%$ formamide at $45^{\circ} \mathrm{C}$ according to Alwine et al. (2).

Autoradiographic exposure was for 1-2 days with or without Kodak X-Omatic regular intensifying screens at $-80^{\circ} \mathrm{C}$.

\subsection{Containment}

Organisms containing in vitro recombinant DNA were handled under P1 conditions (15).

\section{RESULTS}

\subsection{Cloning of the $I L V I$ gene}

The wild type $I L V I$ gene was selected by transformation of the haploid S. cerevisiae strain C811431 , which is isoleucine requiring due to the ilvl-23 mutation and carries the marker trpl: About $3 \cdot 10^{9}$ protoplasts were transformed with $70 \mu \mathrm{g}$ of plasmid DNA from a gene pool consisting of the TRPI-cosmid vector $\mathrm{p} 2911$ with insertions of random fragments of partially $\mathrm{Mbol}$ cleaved S288C yeast DNA (see section 2.5). Selection for transformants which had become $\mathrm{Ile}^{+} \mathrm{Trp}^{+}$on SC-ile-trp sorbitol agar plates yielded a total of 155 colonies. Parallel plating on SC-trp revealed that there was one $\mathrm{Ile}^{+} \mathrm{Trp}^{+}$transformant per $700 \mathrm{Trp}^{+}$transformants. Twenty one $\mathrm{Ile}^{+} \mathrm{Trp}^{+}$transformants were isolated. Seven of these were unstable for the Ile+Trp+ phenotype, whereas the remaining 14 transformants were stable Ile+Trp ${ }^{+}$, probably due to integration of the 
transforming plasmid into the yeast chromosome by sequence homology.

Plasmid DNA from one unstable transformant was used to transform E. coli strain HB101, selecting for ampicillin resistant colonies. A transformant was obtained which was found to contain a large plasmid, designated pC515. Restriction endonuclease digestions with various enzymes showed that this plasmid was composed of cosmid p2911 with an insertion of about $35 \mathrm{~kb}$.

Plasmid pC515 was found to retransform ilvl mutants of yeast to isoleucine independence at the high frequency characteristic for self-replicating plasmids. It complemented ilvl-23, as well as the two other ilvl alleles, ilvl-22 (strain C81-1615) and ilv1-92 (strain C82-1748).

\subsection{Subcloning of the $I L V I$ gene}

To obtain the $I L V l$ gene on a smaller fragment, $10 \mu \mathrm{g}$ of the plasmid pC515 were cleaved with restriction endonuclease Sall and ligated to $20 \mu \mathrm{g}$ of SalI cleaved plasmid pC508. This vector is composed of pBR 325 with the $1.4 \mathrm{~kb}$ yeast $T R P I$ fragment inserted into the EcoRI site. The ligation mixture was used to transform the yeast strain C81-1431. Approximately 600 colonies were obtained on SC-ile-trp regeneration plates. Plasmid DNA was extracted from an unstable Ile+Trp' transformant and used to transform E. coli strain BJ5183. From one of the E. coli transformants, picked at random, we obtained the plasmid pC516, shown in Figure 1. The plasmid is $13.1 \mathrm{~kb}$ and consists of $\mathrm{pC} 508$ with an insertion of approximately $6.2 \mathrm{~kb}$. The structure of pC516

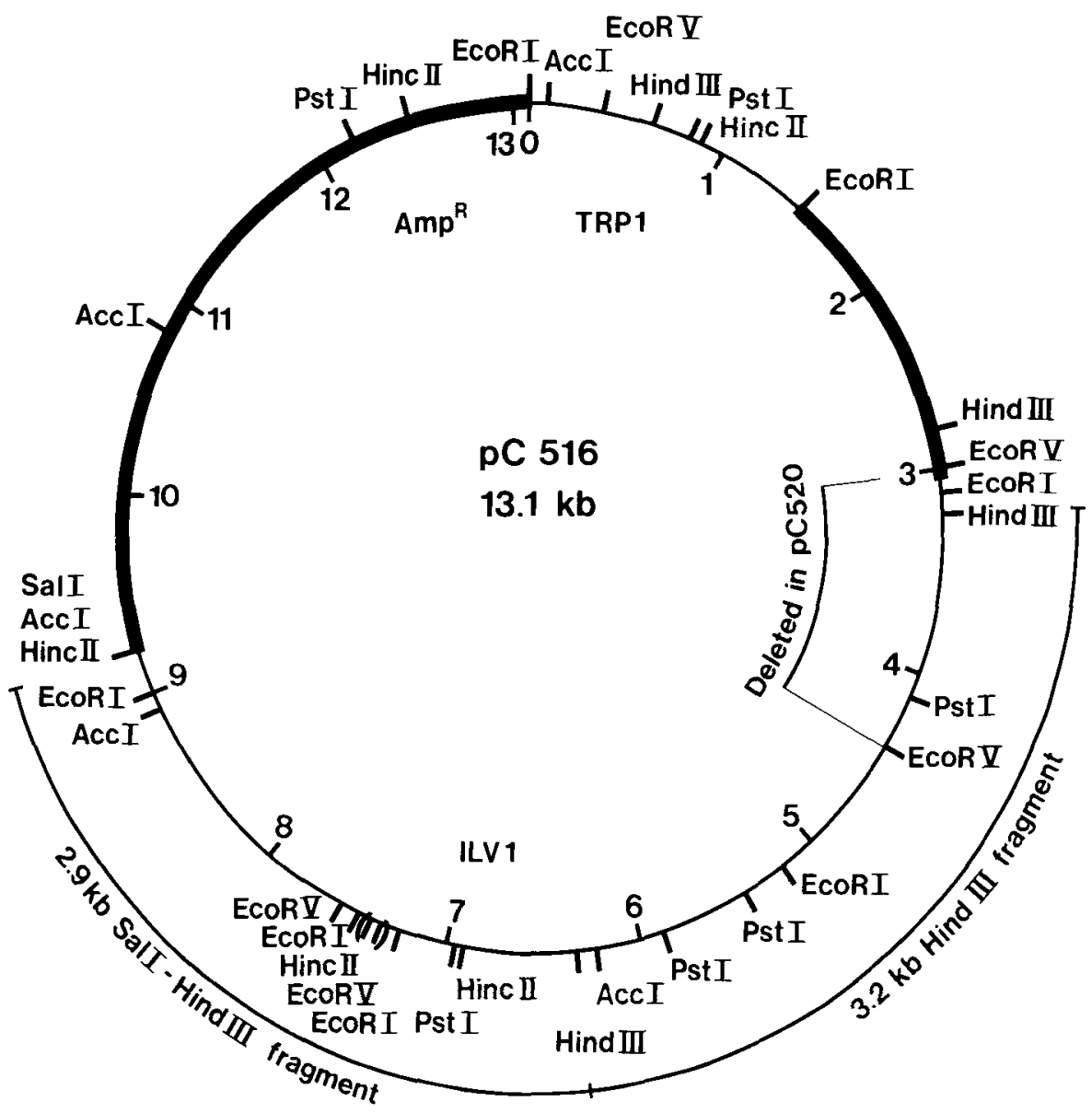

Figure 1. Restriction endonuclease map of the $I L V I$ carrying plasmids pC516 and pC520.

The $I L V I$ gene is present on the two fragments, $3.2 \mathrm{~kb}$ HindIII and $2.9 \mathrm{~kb}$ SalI-HindIII. Heavy lines, pBR325; thin lines, yeast DNA sequences. 


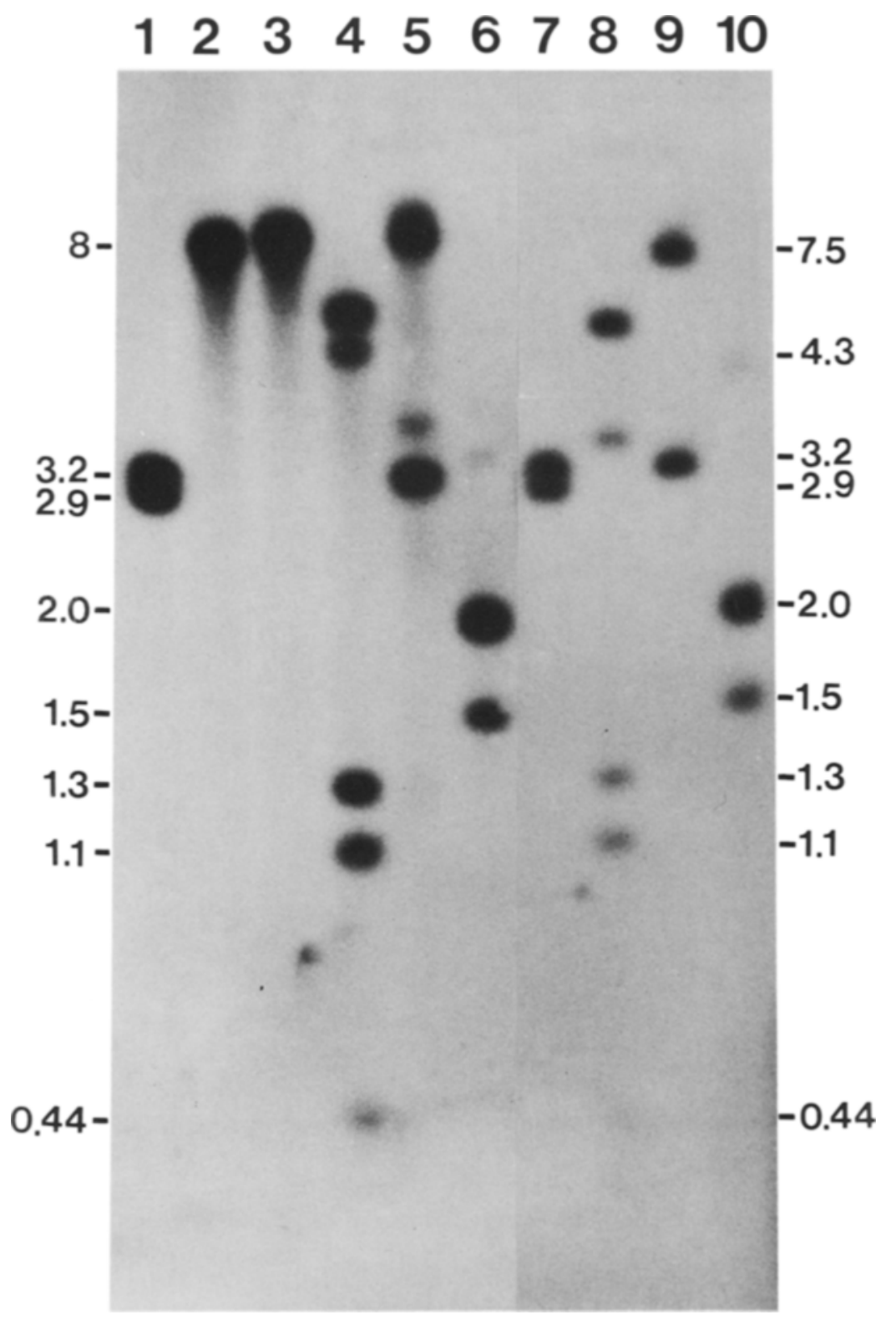

Figure 2. Hybridization of pC516 fragments to restriction digests of yeast DNA and plasmid pC516.

One $\mu \mathrm{g}$ of $32 \mathrm{P}$-labelled $3.2 \mathrm{~kb}$ HindIII fragment $+2.9 \mathrm{~kb}$ SalI-HindIII fragment from $\mathrm{pC} 516$ was hybridized to the following samples: Lane 1, HindIII-Sall double digest of S288C DNA. Lane 2, Sall digest of S288C DNA. Lane 3, BamHI digest of S288C DNA. Lane 4, PstI digest of S288C DNA. Lane 5, HindIII digest of S288C DNA. Lane 6, EcoRI digest of S288C DNA. One $\mu \mathrm{g}$ of DNA was loaded in each of the lanes 1-6. Lane 7, HindIII-Sall double digest of pC516. Lane 8, PstI digest of pC516. Lane 9, HindIII digest of pC516. Lane 10, EcoRI digest of pC516. One ng of DNA was used in lanes 7-10.

is not completely as expected, since it is missing one Sall site as well as a neighbouring part of pC508. It is probable that the DNA molecule that entered C81-1431 to yield the transformant had not been ligated to circularity and was trim- med by exonucleases before in vivo circularization. This would explain the deletion of one end of the Sall insert and about $0.3 \mathrm{~kb}$ of the tetracycline resistance gene. Retransformation experiments show that the plasmid replicates au- 
tonomously in strains C81-1431 and C82-1748, rendering them unstable for the Ile+Trp ${ }^{+}$phenotype.

Plasmid pC516 was further trimmed by partial digestion with EcoRV, followed by self-ligation and transformation of $\mathrm{E}$. coli HBIQ1. This yielded plasmid pC520, which is pC516 without the $1.4 \mathrm{~kb}$ bacterial-yeast DNA EcoRV segment (Figure 1). The insert in plasmid pC520 is $4.8 \mathrm{~kb}$. It transforms strain C82-1748 to Ile+Trp+. The growth and the instability of the transformants were indistinguishable from the pC516 transformants of this strain.

\subsection{Southern blot analysis of yeast DNA}

To ensure that the structure of the insert of pC516 was identical to that in the yeast chromosome, a mixture of equimolar amounts of the 3.2 $\mathrm{kb}$ HindIII fragment and the $2.9 \mathrm{~kb}$ Sall-HindIII fragment of pC516 (see Figure 1) was nick translated and hybridized to S288C DNA cleaved with various restriction enzymes and separated by agarose gel electrophoresis. For comparison, restriction digests of pC516 were analysed as well. The result is shown in Figure 2.

As expected only 2 bands, 3.2 and $2.9 \mathrm{~kb}$ in size, hybridize to the HindIII-Sall double digests of pC516 (lane 7), and S288C DNA (lane 1). The hybridization pattern of the EcoRI digest of pC516 shows 4 bands (lane 10), a $4.3 \mathrm{~kb}$ band (weak hybridization since the fragment mainly contains bacterial sequences), a double band of $2.0 \mathrm{~kb}$ and a $1.5 \mathrm{~kb}$ band. The small EcoRI fragment of $0.2 \mathrm{~kb}$ could not be detected. EcoRI cleaved S288C DNA (lane 6) also shows hybridization to the $2.0 \mathrm{~kb}$ doublet and the $1.5 \mathrm{~kb}$ band, and weaker hybridization to a $3.3 \mathrm{~kb}$ fragment. These patterns, as well as the patterns obtained with PstI (lanes 4 and 8) and HindIII (lanes 5 and 9) show that the cloned DNA in pC516 originates from a contiguous sequence of yeast chromosomal DNA.

\subsection{The ILV1 messenger RNA}

We examined the in vivo expression of the $I L V I$ region by probing RNA extracted from yeast for RNA species complementary to the DNA cloned in pC516. RNA from the wild type strain S288C was electrophoresed on denaturing (formaldehyde) gels and transferred to nitro- cellulose filters. The RNA was then probed with the equimolar mixture of the $3.2 \mathrm{~kb}$ HindIII and the $2.9 \mathrm{~kb}$ Sall-HindIII restriction fragments (Figure 1) comprising most of the insert in pC516. The result is shown in Figure 3. In lanes $1-3$, in which total RNA was fractionated, two transcripts are seen, approximately 2,000 and 950 nucleotides in length. The sizes of the transcripts were determined relative to ribosomal RNA from E. coli, barley chloroplasts and yeast, electrophoresed in the same gel. No other major transcripts are seen when poly(A) RNA is analysed (lanes 4-6).

Figure 3 also gives information about the regulation of the transcripts. A comparison was made between poly(A) RNA from S288C grown in minimal medium plus leucine (lane 5) and minimal medium containing isoleucine, leucine and valine (lane 4). The band intensities of the autoradiogram indicate that at least a 5-fold repression in the level of the the $2 \mathrm{~kb}$ mRNA occurs by the addition of isoleucine and valine to the growth medium, suggesting a specific control of isoleucine and/or valine at the level of transcription. About the same low hybridization is seen for cells grown in YPD medium (lane 6). The repression with isoleucine and valine is also seen when total RNA is analysed (lanes 1 and 3 versus 2 ). Interestingly, a slight repression of the $0.9 \mathrm{~kb}$ transcript seems to occur by the addition of isoleucine and valine. The significant response of the $2 \mathrm{~kb}$ transcript to the addition of isoleucine and valine makes it a likely candidate for the threonine deaminase mRNA. That this is in fact correct was shown by the gene inactivation experiment described below in section 3.7.

\subsection{Mapping of the transcripts}

In order to identify the transcribed regions we isolated a number of DNA restriction endonuclease fragments comprising most of the insert of pC516. The locations of the fragments are shown in Figure 4. Total RNA from S288C grown in minimal medium with leucine was separated by electrophoresis and transferred to nitrocellulose filters. The filters were individually subjected to hybridization with the purified restriction fragments which had been labelled in vitro with $32 \mathrm{P}$ by nick translation. The result is 


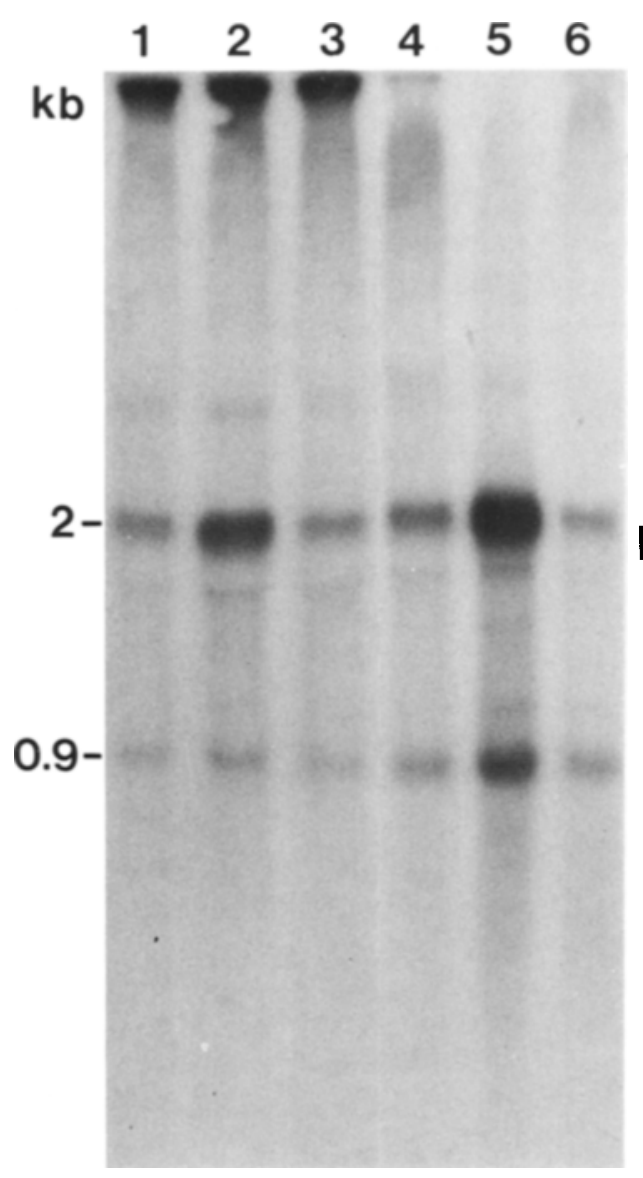

Figure 3. In vivo transcription of the $I L V l$ region.

S288C RNA samples were separated in a formaldehyde containing gel, transferred to a nitrocellulose filter and hybridized with one $\mu \mathrm{g}$ of $32 \mathrm{P}$-labelled $3.2 \mathrm{~kb}$ HindIII $+2.9 \mathrm{~kb}$ Sall-HindIII fragments from pC516. Lane 1, total RNA from cells grown in minimal medium with $5 \mathrm{~mm}$-isoleucine, $5 \mathrm{~mm}$-valine and $5 \mathrm{~mm}$ leucine. Lane 2, total RNA from cells grown in minimal medium with 20 mM-leucine. Lane 3 , total RNA from cells grown in YPD. Twenty $\mu \mathrm{g}$ of RNA were loaded in lanes 1-3. Lane 4, poly(A) RNA from cells grown in minimal medium with $5 \mathrm{~mm}$-isoleucine, 5 mm-valine and 5 mm-leucine. Lane 5, poly(A) RNA from cells grown in minimal medium with $20 \mathrm{~mm}-$ leucine. Lane 6, poly(A) RNA from cells grown in YPD. Ten $\mu \mathrm{g}$ of poly(A) enriched RNA were used in lanes 4-6.

shown in Figure 5. It is seen that probes A, B and $C$ hybridize to the $I L V I$ mRNA, whereas probes $D$ and $E$ do not. This places the end-points of the

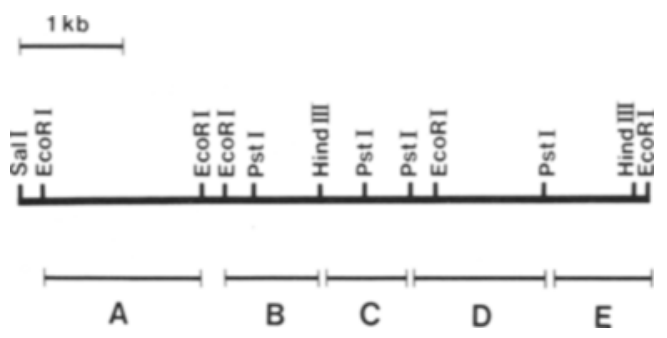

Figure 4. Positions of 5 restriction fragments used to localize the $I L V I$ transcribed region by hybridization to RNA.

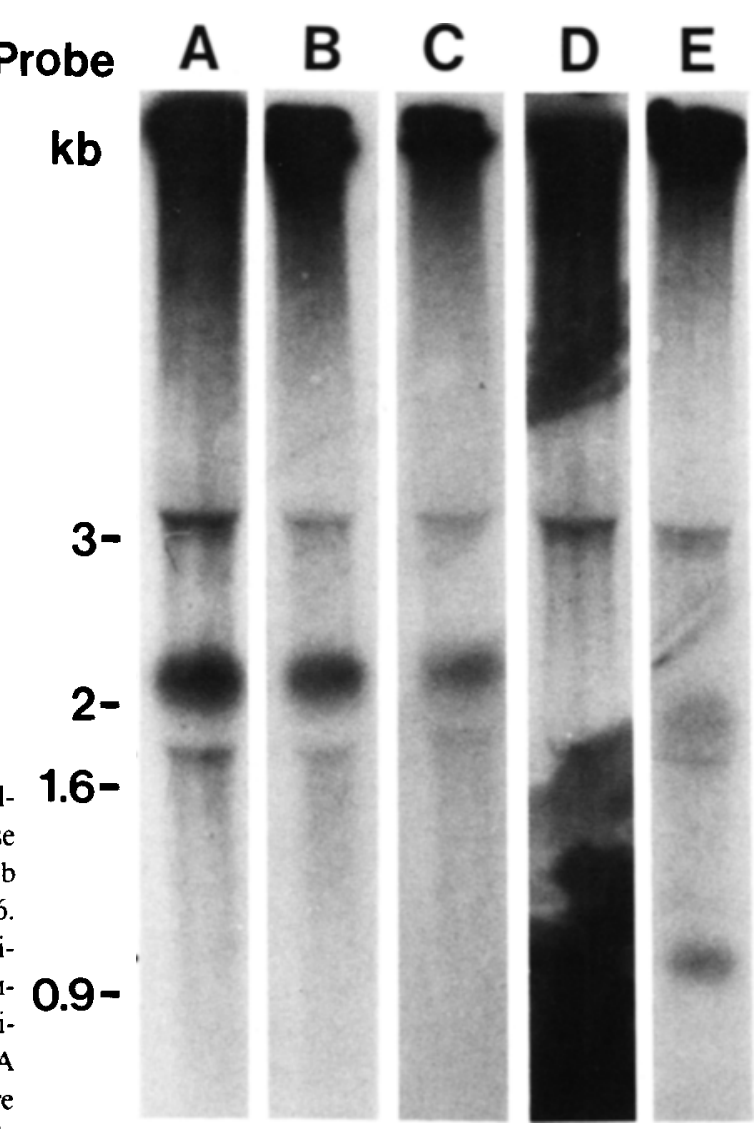

Figure 5. Mapping of the $2 \mathrm{~kb}$ and the $0.9 \mathrm{~kb}$ transcripts.

Fifteen $\mu \mathrm{g}$ of S288C total RNA were loaded in each slot of a formaldehyde containing gel. After electrophoresis, the RNA was transferred to nitrocellulose and hybridized to the five individual probes depicted in Figure 4. (The bands at 3 and $1.6 \mathrm{~kb}$ are regarded as unspecific hybridization occurring at the front of ribosomal RNA bands). 
mRNA in the regions corresponding to probes $A$ and $\mathrm{C}$, consistent with its size of $2 \mathrm{~kb}$ (Figure 6). The $0.9 \mathrm{~kb}$ transcript hybridizes to probe $\mathrm{E}$ and not to probes A, B and C; the analysis with probe $\mathrm{D}$ was inconclusive. The data show that the two RNA species hybridize to separate regions of plasmid pC516. At present we do not know the exact distance between the two transcripts, and we do not know whether pC516 contains a fully functional gene for the small transcript.

\subsection{Functional and genetic identification of the cloned $I L V I$ sequence by plasmid integration}

To confirm that the $2 \mathrm{~kb}$ transcript is indeed the $I L V I$ transcription product, plasmid pC521 was constructed. It consists of pBR322 in which the $0.03 \mathrm{~kb}$ EcoRI-HindIII fragment has been replaced by a $1.1 \mathrm{~kb}$ HindIII fragment containing the yeast $U R A 3$ gene and the $0.93 \mathrm{~kb}$ EcoRIHindIII fragment internal to the $2 \mathrm{~kb}$ transcribed region (fragment B, Figures 4 and 6). Since the plasmid is lacking a yeast replication origin, $\mathrm{Ura}^{+}$ transformants of a ura 3 yeast strain would most likely be the result of integration of the plasmid into the yeast chromosome by homologous recombination. Integration of the plasmid may take place either at the ura 3 locus or at the site from which the $0.93 \mathrm{~kb}$ fragment originates. Integration at the latter site would lead to disruption of the $2 \mathrm{~kb}$ transcribed region. Such splitting of the corresponding wild type gene is expected (39) to inactivate the gene. If an integrating plasmid is cleaved in the yeast DNA insert, it transforms yeast more effectively than the native plasmid and is usually integrated in sequences homologous to the cleaved site (32). Since no unique restriction site was known for the $0.93 \mathrm{~kb}$ insert, the plasmid was cleaved partially with PstI. The plasmid contains three PstI sites: One in the insert, one in the URA3 fragment, and one in the bacterial sequence. Ten $\mu \mathrm{g}$ of the partially digested DNA were used to transform the $I L V I$ yeast strain M1-2B (MAT $\alpha$ ura3-52 trpI) using the cation transformation method (17). The ura3-52 deletion was used to minimize integration at this locus. A total of 134 transformants were recovered on SC-ura plates. Out of 20 randomly picked transformants, seventeen had become isoleucine auxotrophs.
Two of the Ile-Ura+ transformants were analysed genetically. They were crossed to the $[L V I$ hisl ura3 strain K396-11A, sporulated and dissected. Since $i l v l$ and hisl are linked meiotically with a distance of $16 \mathrm{cM}$ on chromosome $\mathrm{V} \mathrm{(30),}$ linkage should be found between the integrated $U R A 3$ gene and hisl, if the site of integration was at ILVI. It should be mentioned that the ura 3 locus is also on chromosome $\mathrm{V}$, but it is located more than $50 \mathrm{cM}$ from both hisl and ilvl. It was found that the Ile-Ura+ phenotype always segregated together in a normal Mendelian 2:2 fashion. The segregation between his $/$ and $U R A 3$ (Ile-) was 15PD:0NPD:8T for the one transformant and 16PD:1NPD:9T for the other, showing significant linkage between hisl and the integrated $U R A 3$ with distances of 17 and $29 \mathrm{cM}$, respectively (33). It is concluded that the $0.93 \mathrm{~kb}$ fragment has disrupted the function of the $I L \mathrm{~V} /$ gene, and thus is located within this gene. This confirms the notion that the $2 \mathrm{~kb}$ RNA is the $[\mathrm{LV}]$ messenger RNA.

\section{DISCUSSION}

We have cloned a yeast DNA fragment which is able to complement $i / v /$ mutations. The conclusion that this segment indeed contains the yeast $I L V /$ gene, is based on the following experiments: 1. The gene complements three different ilvl mutant alleles. 2. Integration of plasmid pC521 into the yeast chromosome leads to isoleucine auxotrophy by gene disruption. 3 . The integrated $U R A 3$ gene of this plasmid, as well as the induced $i l v$ auxotrophy mapped genetically at the ilvl locus. In addition, we have previously shown that the cloned DNA segment originates from chromosome $\mathrm{V}$ by hybridization experiments using a $S$. cerevisiae strain with its chromosome $\mathrm{V}$ substituted by a homeologous $\mathrm{S}$. carlsbergensis chromosome (31).

The genetic fine structure analysis of 27 point mutations at the ilvl locus by THuriaux et al. (44) showed that it consists of only one cistron. Interallelic complementation at ilvl suggested that the product was composed of at least two identical polypeptide chains. From the genetic length an estimate of 2,400-3,200 nucleotides was obtained for the physical size of the gene. In addition, they determined the translation start 
codon to be at the centromere proximal end of ILVl.

We have determined the ILVI mRNA to be approximately 2,000 ribonucleotides in length. Assuming 300-350 untranslated bases, including the poly(A) tail, and a molecular weight of 110 for one amino acid, the threonine deaminase subunit would have a molecular weight of about 60,000 . This is in agreement with the published value of 50,000 (1).

The regulation of threonine deaminase levels in yeast has been studied by BUSSEY and UMBARGER (12). They found that this enzyme, together with the other four isoleucine-valine biosynthesis enzymes, is multivalently regulated by isoleucine, valine and leucine. They observed about a 2-fold increase in threonine deaminase activity in minimal medium with leucine, as compared to medium with isoleucine (or threonine), valine and leucine. BOLLON (8) found that threonine deaminase was repressed by isoleucine alone. The threonine deaminase activity was 2 times higher for cells grown in minimal medium or minimal medium with leucine than in medium containing isoleucine alone or isoleucine, valine and leucine. In agreement with both studies, we observed a significant increase in $I L V I$ mRNA synthesis upon isoleucine and valine starvation, indicating a specific control at the transcriptional level.

\section{ACKNOWLEDGEMENTS}

We thank G. BANK and K. TERKILDSEN for excellent technical assistance and J. Polaina, C. GJERMANSEN and D. vON WETTSTEIN for critical reading of the manuscript. The gift of cosmid p2911 from B. HoHN is highly appreciated. This work was supported by grants 511-20672, 51220779, 516-20214.H-510 and 16-1740.H-547 from the Danish National Research Councils for Natural, Medical and Technical Sciences to D. vON WETTSTEIN.

\section{REFERENCES}

1. Ahmed, S.I., A.P. Bollon, S.J. Rogers \& P.T. MAGeE: Purification and properties of threonine deaminase from Saccharomyces cerevisiae. Biochimie 58, 225-232 (1976)

2. Alwine, J.C., D.J. Kemp \& G.R. Stark: Method for the detection of specific RNAs in agarose gels by transfer to diazobenzyloxymethyl paper and hybridization with DNA probes. Proc. Nat. Acad. Sci. USA 74, 53505354 (1977)

3. BEGGS, J.D.: Transformation of yeast by a replicating hybrid plasmid. Nature 275, 104-108 (1978)

4. Betz, J.L., L.M. Hereford \& P.T. Magee: Threonine deaminases from Saccharomyces cerevisiae mutationally altered in regulatory properties. Biochemistry 10, 1818-1824 (1971)

5. Birngoim, H.C. \& J. Doly: A rapid alkaline extraction procedure for screening recombinant plasmid DNA. Nucleic Acid Res. 7, 1513$1523(1979)$

6. BLAZEY, D.L., R. Kim \& R.O. Burns: Molecular cloning and expression of the ilvGEDAY genes from Salmonella typhimurium. J. Bacteriol. 147, 452-462 (1981)

7. BOLLON, A.P.: Fine structure analysis of a eukaryotic multifunctional gene. Nature 250, 630-634 (1974)

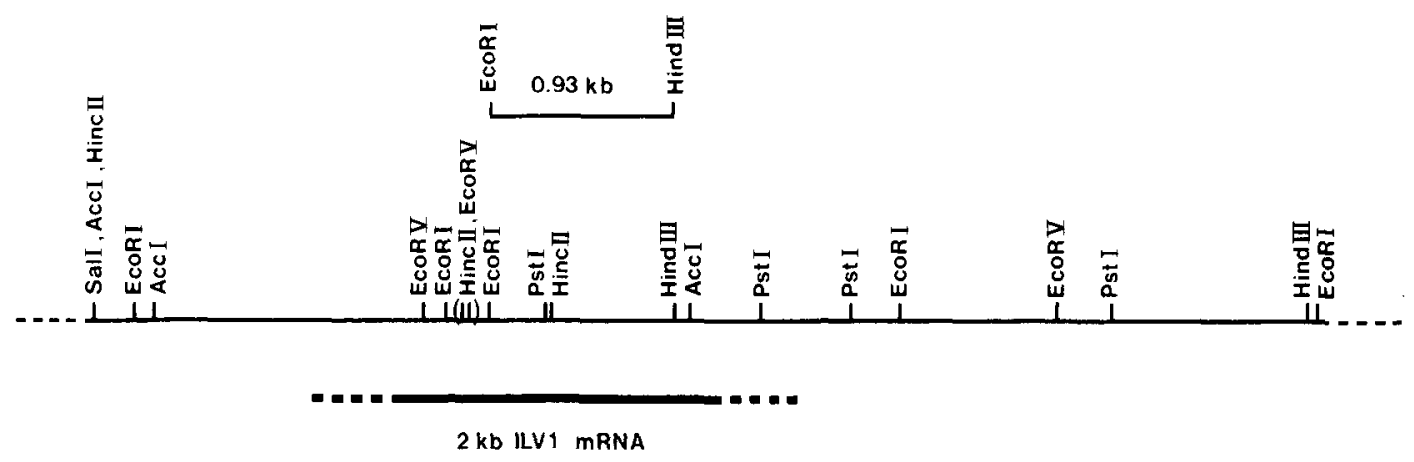

Figure 6. Structural and transcriptional map of the $I L V I$ region in yeast.

The approximate location of transcription for the $I L V I$ mRNA is shown, as well as the position of the $0.93 \mathrm{~kb}$ EcoRI-HindIII fragment demonstrated by gene splitting to be internal to the $I L V I$ gene. 
8. BolLon, A.P.: Regulation of the $i l v l$ multifunctional gene in Saccharomyces cerevisiae. Mol. Gen. Genet. 142, 1-12 (1975)

9. Bollon, A.P. \& P.T. MAGEE: Involvement of threonine deaminase in multivalent repression of the isoleucine-valine pathway in Saccharomyces cerevisiae. Proc. Nat. Acad. Sci. USA. $68,2169-2172$ (1971)

10. BOLLON, A.P. \& P.T. MAGEE: Involvement of threonine deaminase in repression of the isoleucine-valine and leucine pathways in Saccharomyces cerevisiae. J. Bacteriol.113, 13331344 (1973)

11. Broach, J.R., J.F. Atkins, C. MCGill \& L. CHOw: Identification and mapping of the transcriptional and translational products of the yeast plasmid, $2 \mu$ circle. Cell $16,827-839$ (1979)

12. BuSSEY, H. \& H.E. UMBARGER: Biosynthesis of branched-chain amino acids in yeast: Regulation of synthesis of the enzymes of isoleucine and valine biosynthesis. J. Bacteriol. 98, 623628 (1969)

13. Calmoun, D.H. \& J.E. Gray: Cloning of the ilvA538 gene coding for feedback-hypersensitive threonine deaminase from Escherichia coli K-12. J. Bacteriol. 151, 274-280 (1982)

14. Delforge, J., F. Messenguy \& J. Wiame: The regulation of the arginine biosynthesis in Saccharomyces cerevisiae: The specificity of $\arg R$ mutations and the general control of amino acid biosynthesis. Eur. J. Biochem. 57, 231-239 (1975)

15. Guidelines for research involving recombinant DNA molecules. Federal Register U.S. 47 (77), 17180-17198 (1982)

16. Holmberg, S., J.G.L. Petersen, T. NilssonTillgren \& M.C. Kielland-Brandt: Molecular characterization of a Saccharomyces plasmid containing the HIS4 gene. Carlsberg Res. Commun. 44, 269-282 (1979)

17. Ito, H., Y. Fukuda, K. Murata \& A. Kimura: Transformation of intact yeast cells treated with alkali cations. J. Bacteriol. 153, 163-168 (1983)

18. JONES, E.W. \& G.R. FinK: Regulation of amino acid and nucleotide biosynthesis in yeast. In: The Molecular Biology of the Yeast Saccharomyces. Metabolism and Gene Expression. J.N. Strathern, E.W. Jones \& J.R. Broach, eds. Cold Spring Harbor, New York, vol. 11B, pp. 181-299 (1982)

19. Katsunuma, T., S. Elsässer \& H. Holzer: Purification and properties of threonine dehydratase from yeast. Eur. J. Biochem. 24, 83-
97 (1971)

20. Katz, L., D.T. Kingsbury \& D.R. HelinsKI: Stimulation by cyclic adenosine monophosphate of plasmid deoxyribonucleic acid replication and catabolic repression of the plasmid deoxyribonucleic acid-protein relaxation complex. J. Bacteriol. 114, 577-591 (1973)

21. Kielland-Brandt, M.C., T. NilsSonTillgren, S. Holmberg, J.G.L. Petersen \& B.A. Svenningsen: Transformation of yeast without the use of foreign DNA. Carlsberg Res. Commun. 44, 77-87 (1979)

22. Klapholz, S. \& R.E. Esposito: A new mapping method employing a meiotic Rec- mutant of yeast. Genetics 100, 387-412 (1982)

23. Kovaleva, S.V., A.I. Dorozhko, N.F. Belayeva \& Z.S. KAGAN: Comparative kinetic properties of structure-bound and solubilized L-threonine dehydratase from brewers yeast. Biokhimiya (Moscow) 44, 1906-1911 (1979)

24. Lehrach, H., O. Diamond, J.M. Wozney \& H. BOEDTKER: RNA molecular weight determinations by gel electrophoresis under denaturing conditions, a critical reexamination. Biochemistry 16, 4743-4751 (1977)

25. Lessie, T.G. \& H.R. Whiteley: Properties of threonine deaminase from a bacterium able to use threonine as sole source of carbon. J. Bacteriol. 100, 878-889 (1969)

26. Livingston, D.M. \& H.L. Klein: Deoxyribonucleic acid sequence organization of a yeast plasmid. J. Bacteriol. 129, 472-481 (1977)

27. Mandel, M. \& A. Higa: Calcium dependent bacteriophage DNA infection. J. Mol. Biol. 53, 159-162 (1970)

28. Maniatis, T., E.F. Fritsch \& J. Sambrook: Molecular Cloning. A Laboratory Manual. Cold Spring Harbor, New York, pp. 264-267 (1982)

29. MCCorkle, G.M., T.D. Leathers \& H.E. UMBARGER: Physical organization of the ilvGEDA genes of Escherichia coli K-12. Proc. Nat. Acad. Sci. USA 75, 89-93 (1978)

30. Mortimer, R.K. \& D. SCHILD: Genetic map of Saccharomyces cerevisiae. Microbiol. Rev. 44, 519-571 (1980)

31. Nilsson-Tillgren, T., M.C. KiellandBrandt, S. Holmberg, J.G.L. Petersen \& C. GJERMANSEN: Is lager yeast a species hybrid? Utilization of intrinsic genetic variation in breeding. Proc. 4th Int. Symp. on Genetics of Industrial Organisms, Kyoto, pp. 143-147 (1982)

32. OrR-Weaver, T., J.W. Szostak \& R.J. RothSTEIN: Yeast transformation: A model system 
for the study of recombination. Proc. Nat. Sci. USA 78, 6354-6358 (1981)

33. Perkins, D.D.: Biochemical mutants in the smut fungus Ustilago maydis. Genetics 34, 607-626 (1949)

34. Petersen, J.G.L., M.C. Kielland-Brandt, S. Holmberg \& T. Nilsson-Tillgren: Mutational analysis of isoleucine-valine biosynthesis in Saccharomyces cerevisiae. Mapping of ilv2 and ilv5. Carlsberg Res. Commun. 48, 21- 34 (1983)

35. Rigby, P.W.J., M. Dieckmann, C. Rhodes \& P. BERG: Labeling of deoxyribonucleic acid to high specific activity in vitro by nick translation with DNA polymerase I. J. Mol. Biol. 113, 237-251 (1977)

36. de Robichon-Szulmajster, H. \& P.T. Magee: The regulation of isoleucine-valine biosynthesis in Saccharomyces cerevisiae. 1. Threonine deaminase. Eur. J. Biochem. 3, 492501 (1968)

37. Ryan, E.D. \& G.B. Kohlhaw: Subcellular localization of isoleucine-valine biosynthetic enzymes in yeast. J. Bacteriol. 120,631-637 (1974)

38. Satayanarayana, T., H.E. Umbarger \& G. LINDEGREN: Biosynthesis of branched-chain amino acids in yeast: Regulation of leucine biosynthesis in prototrophic and leucine auxotrophic strains. J. Bacteriol. 96, 2018-2024 (1968)

39. Shortle, D., J. Haber \& D. Botstein: Lethal disruption of the yeast actin gene by integrative transformation. Science 217, 371-373 (1982)

40. Souciet, J.-L., J.-C. Hubert \& F. Lacroute: Cloning and restriction mapping of the yeast LRA2 gene coding for the carbamyl phosphate synthetase aspartate-transcarbamylase complex. Mol. Gen. Genet. 186, 385-390 (1982)

41. SOUTHern, E.M.: Detection of specific DNA sequences among DNA fragments separated by gel electrophoresis. J. Mol. Biol. 98, 503-517 (1975)

42. ST John, T.P., S. SCherer, M.W. MCDONELl \& R.W. Davis: Deletion analysis of the Saccharomyces $G A L$ gene cluster. J. Mol. Biol. $152,317-334$ (1981)

43. Struhl, K., D.T. Stinchcomb, S. Scherer \& R.W. DAvIS: High-frequency transformation of yeast: Autonomous replication of hybrid molecules. Proc. Nat. Acad. Sci. USA 76, 1035-1039 (1979)

44. Thuriaux, P., M. Minet, A.M.A. Ten Berge \& F.K. ZIMMERManN: Genetic fine structure and function of mutants at the $i l v /$ gene locus of Saccharomyces cerevisiae. Mol. Gen. Genet. 112, 60-72 (1971)

45. Ulm, E., R. Böhme \& G. Kohlhaw: $x$-isopropylmalate synthase from yeast: Purification, kinetic studies and effect of ligands on stability. J. Bacteriol. 110, 1118-1126 (1972)

46. UMBARGER, H.E.: Amino acid biosynthesis and its regulation. Ann. Rev. Biochem. 47, 533606 (1978)

47. Wolfner, M., D. Yep, F. Messenguy \& G.R. FINK: Integration of amino acid biosynthesis into the cell cycle of Saccharomyces cerevisiae. J. Mol. Biol. 96, 273-290 (1975)

48. YANG, R.C.-A., J. LIS \& R. WU: Elution of DNA from agarose gels after electrophoresis. In: Methods in Enzymology, R. Wu, ed. Academic Press, New York, vol. 68, pp. 179-182 (1979) 